\title{
The impact of personal interactions on the stress of school administrators: The validation and application of an assessment tool
}

\author{
Eloy López Meneses $^{1}$ (D) Juan J. Leiva Olivencia² ${ }^{\text {ID }}$, Esteban Vázquez-Cano ${ }^{3}$ \\ ${ }^{1}$ Universidad Pablo de Olavide (Spain) \\ ${ }^{2}$ Universidad de Málaga (Spain) \\ ${ }^{3} U N E D$ (Spain) \\ elopmen@upo.es,juanleiva@,uma.es,_evazquez@,edu.uned.es
}

Received January, 2017

Accepted March, 2017

\section{Abstract}

Purpose: To analyze personal interactions as one of the possible factors that can generate greater stress in school administrators. For this purpose, we present the design, validation and application of a survey that intends to measure the type of managerial functions that are associated with higher rates of personal interaction and their possible measurement as stressors of those performing administrative functions.

Design/methodology: To develop, validate and apply an assessment tool to measure the stress of school administrators. To this end, a mixed analysis methodology has been adopted, involving the selection of a group of experts, the calculation of an "expert proficiency coefficient" (Cabero \& Barroso, 2013) and the subsequent validation of the survey using the modified Delphi method in two phases, with a sample of 30 school administrators and educational supervisors. The survey has also been subjected to a process to determine the trustworthiness and validity of the construct through exploratory and confirmatory factor analysis. 
Findings: The result is a 5-dimension, 31-item survey with a total score of 155 points and three measurements: low stress (1-50 points), medium stress (51-100 points) and high stress (101-155 points).The areas that generate the greatest amount of stress can be summarized in two categories: reprimanding teachers for non-performance of their duties and discipline management at the center (expulsions, bullying, fighting and drugs).

Research limitations/implications: The survey was designed according to the socioeducational characteristics of the Spanish context. Further research in other educational contexts would require an adaptation of different items on the scale.

Practical implications: Measuring the school administrator's stress makes it possible to identify those functions that are more susceptible to intervention, both formative and administrative. This improves one of the key areas of school organization.

Social implications: The improvement of the school institution and its governance starts with identifying those aspects that require educational interventions, but also social ones that imply a reflection on how schools in the 21 st century are managed and organized.

Originality/value: There are no Spanish studies that propose assessment tools to measure the stress of school administrators; in this sense, this study provides a framework for the Spanish context.

Keywords: Personal interaction, School management, Managerial functions, Schools, Stressors, Scale of measurement

Jel Codes: I12, I18, I21

\section{Introduction}

The performance of administrative functions in educational centers usually involves high levels of stress among the school personnel who perform these tasks (Cushing, Kerrins \& Johnstone, 2003; Queen \& Queen, 2005).The stress experienced by school administrators shares certain indicators with other professions or contexts, but it has one very specific idiosyncrasy; primarily, that it is associated with relationships and dealing with members of the educational community: faculty, students, family, administration and external agents. Besides different management, school organization and administrative tasks set out in the corresponding legislation, school administrators must perform other 
informational, mediating and sanctioning tasks, among others, based on the principle of information and collaboration with the educational community. This implies a high level of personal interaction in which different stressful situations can arise that can condition the climate of the center, the school environment and the performance of the administrative function itself, thus affecting the climate surrounding the relationships at the educational centers. While personal relations in education have been studied in great detail, the possible socio-professional implications of personal relations between the members of the administrative team and the rest of the educational community have not been studied in depth.

\section{The administrative function, stress and personal interactions}

The administrative function is considered key and crucial to the organization and the improvement of the quality of the educational centers. Many works have shown the importance of administration in the effectiveness and quality of education. Every day, it is seen more clearly that "the good functioning of an educational center depends to a great extent on the capacity of its administrative team" (VázquezCano, Sevillano \& Méndez, 2011, pp. 47; OECD, 2014; Vázquez-Cano, 2017). The job of school administrators is associated with the good functioning of the educational institution, primarily in these different dimensions: the organization of the work of the faculty, organization of the school and relations between the school and the community (Hallinger, Bickman \& Davis, 1996; Bell, Bolam \& Cubillo, 2003; Aydin, Sarier \& Uysal, 2013; Vázquez-Cano, 2016). In other words, the administrative work conditions the school climate and the labor and socio-educational conditions of those who form part of the educational community. The latest TALIS report (OECD, 2014) shows that school administrators usually dedicate $41 \%$ of their time to administrative tasks and meetings, $21 \%$ to curriculum-related tasks, $15 \%$ to interacting with students, $11 \%$ to relations with parents and $7 \%$ to maintaining relations with local institutions. This means that more than a third of the time spent on administrative functions is associated with personal relations. Likewise, managing socio-professional relations is one of the eight aspects considered to be exponents of quality and excellence in the EFQM model (Hildebrandt, Kristensen, Kanji \& Dahlgaard, 1991). The logic behind the model is based on the idea that achieving excellent results is directly related to leadership capacity, the quality of the strategy and its deployment through people, resources and processes.

The administrative function in schools of the 21 st century cannot be understood solely as the labor performed by the school principal, rather as the joint work of all the members of the administrative team: the principal, the head of studies and the secretary. The literature to date reflects studies on the 
main stressors of school administrators, personalized in the figure of the school principal and considered from different conceptual perspectives. The analysis from the perspective of the "burnout syndrome" applied to the performance of the administrative function has been carried out based on the three most common models: the "Maslachian" model (Maslach, 1982; Maslach, Schaufeli \& Leiter, 2001; Maslach, 2003); the positioning model by Pines and Aronson (1988) and Friedman's theory (1995), among others. In their adaptation of "burnout syndrome" to the performance of the administrative function, these three models use two macrocategories of stressors as a reference (TejeroGonzález \& Fernández-Díaz, 2007): “organizational factors” (role conflicts, role ambiguities, work overload, lack of control, little organizational support, poor relationship climate, poor compensation, and other situational adversities) and "personal factors" (non-resistance, type-A personality pattern, external locus of control, personality with neurotic traits, avoidance or escape conflict style, and low self-efficacy).

Likewise, the effect of stress in the teaching profession has been widely studied and in particular, this stress is compounded in the case of the administrative team (Gilman \& Lanman-Givens, 2001; Friedman, 2002; Cushing et al., 2003; Queen \& Queen, 2005). Different studies have linked personal relations with the faculty and parents in the performance of the administrative function as one of the factors that most increases stress among administrators (Gmelch \& Swent, 1981; Whitaker, 1995; Whan \& Thomas, 1996; Troman, 2000; Grubb \& Flessa, 2006; De Leon, 2006; Combs, Edmonson \& Jackson, 2009). Likewise, the European Agency for Safety and Health at Work (2009) has identified stress as one of the factors that most affects the professional development of educators (and which is $28.5 \%$ greater than in other labor sectors). The studies underscore the problem associated with dealing with parents, students and teachers who have problems of a disciplinary nature in the educational center. For example, a study by Friedman (2002) that intended to predict the greatest stressors among school administrators revealed that one of the factors with the greatest incidence were the irrational demands of parents and their inappropriate behavior in meetings. Another study conducted in Canada (Sarros, 1988, pp. 180) quantified the incidence of personal relations on the stress of administrators at levels greater than 50\%. Pawlas (1996) also analyzed the main stressors of school administrators, highlighting the following causes of stress: problems with staff members and parents, work overload, anticipation of problems, lack of time and inadequate support from the administrations (Tejero-González \& Fernández-Díaz, 2010).

Similarly, other studies, such as those by Cooper and Kelly (1993) with a large sample of 2368 school administrators in the United Kingdom, concluded that the stressors that show the greatest capacity to predict job dissatisfaction and poor mental health are work overload and the management of 
relationships with staff. This phenomenon has also been identified in different educational contexts; for example, in Islamic countries, reference is also made to the problem in studies identifying personal relations as the main stressors of those performing administrative functions (Halim, Samsudin, Meerah \& Osman, 2006; Harris \& Adams, 2007).

In the context of Spanish education, the performance of the administrative function is regulated under Article 132 (LOMCE [Educational Quality Improvement Act], 2013) and Article 30 of Royal Decree 83/1996 (Real Decreto, 1996). Under these regulations, the performance of the administrative function implies a high rate of interaction between the different members of the educational community: students, families, faculty, education inspectors and external agents (police, social services, etc.). In the Spanish context, research work by Álvarez (1993) has identified the lack of means and personal resources for management as one of the factors of stress. Armas (1996) identifies the resolution of problems, conflicts and differences among members of the educational community as a stress factor. Administrative tasks focused on the staff are considered to provide the quintessential social and strategic value. Persons are considered to be the fundamental element of the revitalization and change in organizations. Thus, management that takes into account this factor will increase its capacity to generate knowledge, promote innovation and change, and, in short, make organizations more competitive, leaders in both immediate and remote environments.

The study of possible stressors related to socio-professional relationships of the administrative team has not been sufficiently developed to date, and according to the perception of many practicing professionals, they make up one of the main stress factors in the performance of the administrative function. Likewise, the study of stressors must be based on how they fit in the educational system that we wish to analyze, since it depends to a great degree on the socio-professional characteristics and conditions of the educators who engage in the administrative function in this context. For this reason, a deep reflection and analysis becomes necessary of how personal interaction can affect the stress levels of school administrators by designing scales and instruments that provide reliable results in order to be able to later apply training, organizational and personnel management measures that can support an improvement in the performance of administrative functions, and by extension, in the educational quality in schools. 


\subsection{Objectives}

- To design and then validate the survey: "The incidence of personal interactions on the stress of school administrators".

- To analyze the validity of the content and the construct of the survey, along with its reliability.

\section{Methodology}

The determination of the level of incidence of the "personal interaction" variable (broken down into the different administrative functions that involve the different members of the educational community and external agents for their performance) as a stress factor in the execution of the school administrative function is a very singular aspect involving different qualitative and subjective variables. Their determination requires the participation of the faculty members who have engaged in -or continue to engage in- administrative tasks in any of the administrative positions ("principal" or "head of studies") in order to generate a survey that covers a number of indicators and situations that are decisive enough to be able to assess and measure their incidence on the stress of school administrators. For this reason, the research has adopted a triangular structure among the phases.

\subsection{Phase One: Determination of expert judgment}

In the first phase, we intend to define the representativeness criterion for the participation of experts in the design of the survey, using the "expert competence coefficient" technique (Murray \& Hammons, 1995; Mengual, 2011; Cabero \& Barroso, 2013). The criterion that was used to select the experts was that the participants had been or are currently members of an administrative team or education inspectors, with vast knowledge of the internal workings of education centers. The expert competence of those selected was calculated based on what is referred to as the "expert competence coefficient" or "K coefficient” (García \& Fernández, 2008; López, 2008). To calculate the "expert coefficient”, we asked a series of questions in a double dimension: questions 1 for variable " $\mathrm{Kc}$ " and questions 2 for variable "Ka". The coefficient is obtained by applying the following formula (Cabero \& Barroso, 2013): $\mathrm{K}=1 / 2(\mathrm{Kc}+\mathrm{Ka})$; where $\mathrm{Kc}=$ "knowledge coefficient" or information that the expert has about the proposed topic or problem, which is calculated based on the assessment made by the expert $\mathrm{him} /$ herself on a scale of 0 to 10 , multiplied by 0.1 ; and $\mathrm{Ka}=$ what is referred to as the "justification coefficient" or the rationale for the judgments of the experts, which is obtained by assigning a series of scores to different sources of justification that the expert could provide. 
To implement this technique, the scientific literature recommends different numbers of experts, ranging from 7 to 50; however, it is agreed that the number of participants should be limited to no more than 50 (Williams \& Webb, 1994; Witkin \& Altschuld, 1995; Landeta, 2002; Powell, 2003; García \& Fernández, 2008). Taking into consideration the scientific literature, the number of experts who initially participated in the implementation was 45 , and they worked at a total of 30 primary or secondary schools, or were education inspectors (Table 1).

\begin{tabular}{|l|r|r|r|}
\hline $\begin{array}{c}\text { Phase I. } \\
\text { Design }\end{array}$ & N & $\begin{array}{c}\text { Years of administrative experience } \\
\text { Mean }\end{array}$ & $\begin{array}{c}\text { Years of inspection } \\
\text { experience } \\
\text { Mean }\end{array}$ \\
\hline Administrators & 35 & 5.7 & \\
\hline Inspectors & 10 & 6.1 & 5.8 \\
\hline
\end{tabular}

Table 1. Sample participating in the design and validation phases

\subsection{Phase Two: Design procedure using the Delphi technique}

In the second phase, the Delphi method technique was implemented (Patton, 1987). This is an appropriate method for survey design when the problem is not suitable for the use of a precise analytic technique, but it can benefit from subjective judgments on a group basis (Cabero, 2014). To design the survey, we have used a modified version, the two-round "Modified Delphi”. In its implementation, we must pay special attention to a series of aspects: ensuring the anonymity of the participants, and more specifically, their answers; using different iterations; establishing feedback control by the coordinating group; and using statistical techniques in the analysis of the responses (Rowe \& Wright, 1999). To implement the Delphi method, five phases were applied:

1. Drafting of the first list of topics, with the descriptors that could be included.

2. First round of the Delphi study.

3. Analysis of the results obtained and the drafting of a new list.

4. Second round of the Delphi study.

5. Analysis of the results obtained and drafting of the validation scale.

This first version was organized into 5 blocks of 40 proposed topics; participants were asked to evaluate them according to a scale of 1 to 5 , where 1 is equivalent to not at all important and 5 is very important. They were also asked to give their opinion on a series of aspects: a block of contents that 
they would eliminate or include or any items they would suggest eliminating, including or modifying within the proposed blocks of contents.

\subsection{Phase Three: Exploratory and confirmatory analysis}

In the third phase, the internal consistency of the proposed survey was checked by means of an exploratory and confirmatory analysis, with a sample of 112 administrators and education inspectors (Table 2).

\begin{tabular}{|l|r|r|r|}
\hline $\begin{array}{c}\text { Phase II. } \\
\text { Validation }\end{array}$ & N & $\begin{array}{c}\text { Years of administrative experience } \\
\text { Mean }\end{array}$ & \multicolumn{1}{c|}{$\begin{array}{c}\text { Years of inspection } \\
\text { experience } \\
\text { Mean }\end{array}$} \\
\hline Administrators & 80 & 5.2 & \\
\hline Inspectors & 21 & 4.9 & 5.2 \\
\hline
\end{tabular}

Table 2. Sample participating in the design and validation phases

Once the survey had been designed using the Delphi technique and the expert coefficient, the sample was expanded by 60 administrators and inspectors to obtain a sample of 101 participants to whom the survey was administered. This sample size meets the recommendations of Lloret-Segura, FerreresTraver, Hernández-Baeza and Tomás-Marco (2014), who established a sufficient size of 100 cases (as long as the provision is met that there are three factors, with three or four items each, or when there are more items and factors, but the communalities are greater than .80). To confirm this circumstance and the relationship between the different items on the scale, an exploratory factor analysis was conducted with SPSS, followed by a confirmatory analysis with the EQS program (Bentler, 2006) to check the goodness of fit of the hypothetical measurement model. To do this, the Maximum Likelihood (ML) estimation method was used, in addition to the Robust Maximum Likelihood method (in case there was no multivariate normal distribution). Since the chi-square is sensitive to sample size, experts recommend using other fit indexes, such as CFI, NNFI and RMSA (Bentler, 1990). RMSEA values below .05 indicate an optimal fit, while values above .08 indicate a poor fit (Browne \& Cudeck, 1993). Values above .90 indicate a good fit for NNFI and CFI (Hoyle, 1995). 


\section{Results}

\subsection{Results for Phase One: Determination of expert judgment}

Table 3 shows the scores usually used to evaluate the sources of justification.

\begin{tabular}{|l|r|r|r|}
\hline \multicolumn{1}{|c|}{ Source of Justification } & \multicolumn{2}{c|}{$\begin{array}{c}\text { Degree of influence of each } \\
\text { source on its criteria }\end{array}$} \\
\cline { 2 - 4 } & $\begin{array}{c}\mathbf{H} \\
\text { (High) }\end{array}$ & $\begin{array}{c}\text { M } \\
\text { (Medium) }\end{array}$ & \multicolumn{1}{c|}{$\begin{array}{c}\text { L } \\
\text { Low) }\end{array}$} \\
\hline $\begin{array}{l}\text { Administrative experience in a school as head of studies } \\
\text { (low 2 years / medium 4 years / high more than 4 years) }\end{array}$ & 0.3 & 0.2 & 0.1 \\
\hline $\begin{array}{l}\text { Administrative experience in a school as principal } \\
\text { (12 years / medium 4 years / high more than 4 years) }\end{array}$ & 0.5 & 0.4 & 0.2 \\
\hline Attendance at school leadership courses & 0.05 & 0.05 & 0.05 \\
\hline Theoretical knowledge about the topic of foreign authors & 0.05 & 0.05 & 0.05 \\
\hline Theoretical knowledge about the topic of Spanish authors & 0.05 & 0.05 & 0.05 \\
\hline Own experience regarding the status of the problem & 0.05 & 0.05 & 0.05 \\
\hline
\end{tabular}

Table 3. Evaluation of the sources of justification for the "justification coefficient" (Ka)

Based on the final values obtained, the experts are classified into three large groups: if $\mathrm{K}$ is greater than 0.8 , greater or lesser or equal to 1 , then there is a great influence by all the sources; if $\mathrm{K}$ is greater or equal to 0.7 , greater or lesser or equal to 0.8 , then there is a medium level of influence by all the sources; if $\mathrm{K}$ is greater or equal to 0.5 , greater or lesser or equal to 0.7 , then there is a low level of influence by all the sources. We should indicate that, according to the philosophy of the proposal followed to obtain the "expert competence coefficient" (García \& Fernández, 2008; López, 2008; Mengual, 2011), those experts analyzed who have obtained values below 0.8 are not considered, and therefore rejected from the study.

The assessment of different sources by the expert in order to build knowledge about stress factors was organized according to the following areas. We present the mean values and standard deviations obtained below. To interpret them correctly, bear in mind the three options the subject was offered: low (1), medium (2) and high (3) (Table 4). 


\begin{tabular}{|c|c|c|c|c|c|c|c|c|}
\hline \multirow{2}{*}{ Source of Justification } & \multirow{2}{*}{$\mathbf{M}$} & \multirow{2}{*}{ SD } & \multicolumn{2}{|c|}{ Low } & \multicolumn{2}{|c|}{ Medium } & \multicolumn{2}{|c|}{ High } \\
\hline & & & $\mathbf{S}$ & $\%$ & $\mathbf{S}$ & $\%$ & $\mathbf{S}$ & $\%$ \\
\hline $\begin{array}{l}\text { Administrative experience in a school as head } \\
\text { of studies }\end{array}$ & 2.89 & 0.412 & 9 & 19.5 & 17 & 36.9 & 20 & 43.4 \\
\hline $\begin{array}{l}\text { Administrative experience in a school as } \\
\text { principal }\end{array}$ & 2.53 & 0.367 & 5 & 10.8 & 19 & 41.3 & 22 & 47.8 \\
\hline Attendance at school leadership courses & 1.99 & 0.501 & 20 & 43.4 & 11 & 23.9 & 15 & 32.6 \\
\hline $\begin{array}{l}\text { Theoretical knowledge about the topic of } \\
\text { foreign authors }\end{array}$ & 1.81 & 0.502 & 20 & 43.4 & 12 & 26.0 & 14 & 30.4 \\
\hline $\begin{array}{l}\text { Theoretical knowledge about the topic of } \\
\text { Spanish authors }\end{array}$ & 1.91 & 0.588 & 15 & 32.6 & 14 & 30.4 & 17 & 36.9 \\
\hline $\begin{array}{l}\text { Own experience regarding the status of the } \\
\text { problem }\end{array}$ & 2.99 & 0.611 & 2 & 4.3 & 8 & 17.3 & 36 & 78.2 \\
\hline
\end{tabular}

Table 4. Evaluation of different sources by the expert

The analysis of the results reveals that, according to the criteria set out at the start of our work, the 45 experts showed a mean score of 2.35. Once the "knowledge coefficient" (Kc) and the "justification coefficient" (Ka) were obtained using the procedure described above, we could determine the "expert competence coefficient", according to the following formula: $K=1 / 2(\mathrm{Kc}+\mathrm{Ka})$ (Table 5).

\begin{tabular}{|c|c|c|c|c|c|c|c|}
\hline & Kc & $\mathrm{Ka}$ & Kc & & Kc & $\mathrm{Ka}$ & Kc \\
\hline 1 & 0.70 & 0.90 & 0.70 & 24 & 0.90 & 1.00 & 0.95 \\
\hline 2 & 0.60 & 1.00 & 0.90 & 25 & 0.90 & 0.90 & 0.90 \\
\hline 3 & 0.80 & 0.90 & 0.85 & 26 & 0.80 & 0.70 & 0.75 \\
\hline 4 & 0.90 & 0.90 & 0.90 & 27 & 0.70 & 1.00 & 0.85 \\
\hline 5 & 0.90 & 1.00 & 0.95 & 28 & 0.80 & 0.70 & 0.75 \\
\hline 6 & 0.70 & 1.00 & 0.85 & 29 & 0.80 & 0.90 & 0.85 \\
\hline 7 & 0.80 & 0.90 & 0.85 & 30 & 0.70 & 0.70 & 0.85 \\
\hline 8 & 0.60 & 0.80 & 0.80 & 31 & 0.80 & 0.90 & 0.85 \\
\hline 9 & 0.70 & 0.90 & 0.75 & 32 & 0.90 & 0.90 & 0.90 \\
\hline 10 & 0.90 & 1.00 & 0.95 & 33 & 0.60 & 0.60 & 0.80 \\
\hline 11 & 0.80 & 0.90 & 0.85 & 34 & 0.90 & 1.00 & 0.95 \\
\hline 12 & 0.70 & 0.90 & 0.70 & 35 & 0.80 & 0.90 & 0.85 \\
\hline 13 & 0.70 & 1.00 & 0.85 & 36 & 0.80 & 0.70 & 0.75 \\
\hline 14 & 0.80 & 0.90 & 0.85 & 37 & 0.70 & 1.00 & 0.85 \\
\hline 15 & 0.80 & 0.90 & 0.85 & 38 & 0.90 & 0.90 & 0.90 \\
\hline 16 & 0.90 & 1.00 & 0.95 & 39 & 0.80 & 0.70 & 0.75 \\
\hline 17 & 0.60 & 0.70 & 0.80 & 40 & 0.70 & 1.00 & 0.85 \\
\hline 18 & 0.90 & 0.90 & 0.90 & 41 & 0.60 & 1.00 & 0.80 \\
\hline 19 & 0.80 & 0.90 & 0.85 & 42 & 0.60 & 0.70 & 0.80 \\
\hline 20 & 0.60 & 0.70 & 0.80 & 43 & 0.70 & 1.00 & 0.85 \\
\hline 21 & 0.90 & 1.00 & 0.95 & 44 & 0.90 & 1.00 & 0.95 \\
\hline 22 & 0.90 & 0.90 & 0.90 & 45 & 0.60 & 0.70 & 0.80 \\
\hline 23 & 0.80 & 0.80 & 0.870 & 46 & 0.90 & 0.90 & 0.90 \\
\hline
\end{tabular}

Table 5. Knowledge coefficient (Kc), justification coefficient $(\mathrm{Ka})$ and expert competence coefficient $(\mathrm{K})$ obtained for each of the experts 
Taking into consideration the methodological process of determining the expert competence coefficient, experts were not considered with values below 0.8 (excluded from this first phase were cases $1,8,9,12,17,20,23,26,28,30,33,36,39,42$ and 45). This meant a final sample of 30 experts.

\subsection{Results of the survey design using the Delphi technique}

First of all, we present the configuration of the personal data:

\begin{tabular}{|l|}
\hline General data \\
\hline Gender: \\
\hline Age: \\
\hline Marital/personal status: married, single, divorced, with or without children \\
\hline Years of experience on administrative teams: \\
\hline Years of experience in educational inspection: \\
\hline Position currently held on the administrative team: \\
Principal $\square$ \\
Head of studies $\square$ \\
Assistant head of studies $\square$ \\
Secretary $\square$ \\
\hline
\end{tabular}

The initial survey submitted for evaluation by the experts was based on a general question: What situations in your professional work on an administrative team generate the greatest levels of stress? For this purpose, a list of 40 items is proposed that describe situations and/or common actions associated with administrative functions, to be rated on a Likert scale of $1-5$ (where $1=$ Not at all and $5=\mathrm{A}$ lot). Next, the team of experts was asked to assess their relevance with regard to the incidence of the personal interaction in the stress of school administrators. After the first round of the Delphi study was completed, the mean scores and the standard deviations obtained are presented in Table 6 . 


\begin{tabular}{|c|c|c|}
\hline I. Faculty relations & $\mathbf{M}$ & SD \\
\hline 1.Reprimanding faculty members for arriving late to work & 4.013 & 0.893 \\
\hline 2.Reprimanding faculty members for unexcused absences & 4.712 & 0.701 \\
\hline 3.Reprimanding faculty members for poor classroom control & 4.845 & 0.511 \\
\hline $\begin{array}{l}\text { 4. Reprimanding faculty members for not properly attending to their supervision } \\
\text { duties (classroom or recess) }\end{array}$ & 4.799 & 0.405 \\
\hline $\begin{array}{l}\text { 5.Communicating to faculty members complaints about methodology in their } \\
\text { subjects }\end{array}$ & 4.845 & 0.478 \\
\hline 6.Holding faculty meetings & 3.789 & 0.912 \\
\hline 7.Communieating the convening of meetings & 1.213 & 0.534 \\
\hline 8.Presiding over and coordinating faculty meetings & 1.456 & 0.612 \\
\hline 9.Holding Educational Coordination Commission (CCP) meetings & 3.834 & 0.893 \\
\hline 10.Holding school council meetings & 3.711 & 0.893 \\
\hline II.Family relations & M & SD \\
\hline 1.Reporting disciplinary problems with students & 4.239 & 0.800 \\
\hline 2.Reporting unexcused absences by students & 3.654 & 0.564 \\
\hline 3.Imposing and reporting student expulsions & 4.849 & 0.432 \\
\hline 4.Dealing with complaints about grades & 4.013 & 0.765 \\
\hline 5.Dealing with complaints about class/group changes affecting their son/daughter & 3.865 & 0.436 \\
\hline 6.Holding group meetings with parents at the start of the school year & 3.967 & 0.556 \\
\hline 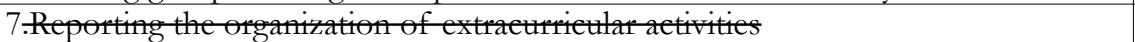 & 1.786 & 0.563 \\
\hline III.Student relations & M & SD \\
\hline 1.Imposing corrective measures that do not involve the expulsion from school & 3.675 & 0.649 \\
\hline 2.Imposing corrective measures that involve the expulsion from school & 4.711 & 0.538 \\
\hline 3.Dealing with cases of harassment/bullying & 4.825 & 0.389 \\
\hline 4.Dealing with matters related to fights resulting in injuries & 4.957 & 0.417 \\
\hline 5.Dealing with theft-related matters & 4.678 & 0.639 \\
\hline 6.Dealing with drug-related matters & 4.965 & 0.543 \\
\hline 7.Dealing with matters related to damage to school property & 4.143 & 0.765 \\
\hline 8.Đealing with maters related to problems duringess & 2.345 & 0.432 \\
\hline 9.Dealing with matters related to students with specific support needs & 3.392 & 0.421 \\
\hline $\begin{array}{l}\text { 10.Dealing with cases of improper use of mobile telephones and other digital } \\
\text { devices }\end{array}$ & 3.876 & 0.486 \\
\hline 11.Dealing with immigrant students & 3.411 & 0.754 \\
\hline 12.Dealing with hygiene-related matters & 4.111 & 0.671 \\
\hline IV.Relations with the School Inspection Department & M & SD \\
\hline 1.Scheduled visits by the inspector & 3.841 & 0.478 \\
\hline 2.Surprise visits by the inspector & 4.125 & 0.603 \\
\hline 3.Administrative evaluation processes & 4.391 & 0.581 \\
\hline 4.Admintostos & 2.106 & 0.542 \\
\hline 5.Grade complaint processes in the edueational administration & 2.089 & 0.498 \\
\hline V. Relations with external agents & $\mathbf{M}$ & SD \\
\hline 1.Interventions by the police & 3.999 & 0.591 \\
\hline 2.Relations with the town council & 3.013 & 0.456 \\
\hline 3.Relations with the educational administration & 3.013 & 0.501 \\
\hline 4.Relations with NGOs & 2.078 & 0.511 \\
\hline 5.Relations with European projects & 1.897 & 0.433 \\
\hline 6.Interention by heatheare workers & 1.341 & 0.611 \\
\hline
\end{tabular}

Table 6. Survey validation

The evaluations by the experts led us to eliminate those items they strongly agreed should be eliminated, or for which the mean value reached was below a score of " 3 " (Dimension 1: items 7-8. Dimension 2: item 7. Dimension 3: item 8. Dimension 4: items 4-5. Dimension 5: items 4-5-6.). After 
the second round, the survey consisted of the following macrocategories and items, in accordance with the results of the mean and standard deviation (Table 7).

\begin{tabular}{|l|r|r|}
\hline Survey areas & \multicolumn{1}{|c|}{ M } & \multicolumn{1}{c|}{ SD } \\
\hline Faculty relations (items 1-8) & 4.31 & 0.71 \\
\hline Family relations (items 9-14) & 4.09 & 0.59 \\
\hline Student relations (items 15-25) & 4.24 & 0.53 \\
\hline Relations with the School Inspection Department (items 26-28) & 4.11 & 0.55 \\
\hline Relations with External Agents (items 27-29) & 3.35 & 0.51 \\
\hline
\end{tabular}

Table 7. Mean and standard deviation of the survey macrocategories

\subsection{Results of the exploratory and confirmatory analysis}

The internal consistency was checked, resulting in a value of $\alpha=.911$. Next, Barlett's sphericity test was applied, the results of which indicated that the data were appropriate for factor analysis, given the significant relationship between the variables: $\chi 2(101)=10,007.102, \mathrm{p}<.000$. The Kaiser-Meyer-Olkin $(\mathrm{KMO})$ test revealed a sample adequacy measure of $\mathrm{KMO}=.881$. These data make it possible to reject the hypothesis that the correlation matrix is not an identity matrix, showing significant interrelationships among the variables, making it acceptable to apply a factor analysis model.

First of all, we carried out a factor analysis with the 31 items that made up the measurement scale, selecting the "Maximum likelihood" option, recommended for later conducting the confirmatory analysis with a five-factor extraction (with Varimax rotation), and eliminating the coefficients with an absolute value $<.40$. The results obtained show a structure that explains $81.305 \%$ of the total variance. Table 8 presents the factor extraction method with the five factors obtained (initial eigenvalues greater than 1) and Table 9 shows the factor weightings.

\begin{tabular}{|c|c|c|c|c|c|c|c|}
\hline \multirow{2}{*}{ Factor } & \multicolumn{3}{|c|}{ Initial eigenvalues } & \multicolumn{3}{|c|}{$\begin{array}{c}\text { Sums of squared saturations of the } \\
\text { extraction }\end{array}$} & \multirow{2}{*}{$\begin{array}{c}\text { Sums of squared } \\
\text { saturations of the rotation }^{a} \\
\% \% \text { variance }\end{array}$} \\
\hline & Total & $\%$ variance & $\%$ cumulative & Total & \begin{tabular}{c|c}
$\%$ \\
variance
\end{tabular} & $\%$ cumulative & \\
\hline 1 & 10.917 & 24.133 & 24.133 & 10.917 & 24.133 & 24.133 & 19.897 \\
\hline 2 & 11.532 & 25.101 & 49.234 & 11.532 & 25.101 & 49.234 & 24.519 \\
\hline 3 & 9.977 & 23.211 & 72.445 & 9.977 & 23.211 & 72.445 & 25.341 \\
\hline 4 & 1.189 & 4.859 & 77.304 & 1.189 & 4.859 & 77.304 & 11.539 \\
\hline 5 & 1.056 & 4.001 & 81.305 & 1.056 & 4.001 & 81.305 & 8.895 \\
\hline
\end{tabular}

Table 8. Factor analysis. Principal axis factoring 


\begin{tabular}{|c|c|c|c|c|c|}
\hline Item & F1 & F2 & F3 & F4 & F5 \\
\hline It1 & .880 & & & & \\
\hline It2 & .771 & & & & \\
\hline It3 & .910 & & & & \\
\hline It4 & .791 & & & & \\
\hline It5 & .780 & & & & \\
\hline It6 & .611 & & & & \\
\hline It7 & .541 & & & & \\
\hline It8 & .567 & & & & \\
\hline It9 & & .756 & & & \\
\hline It10 & & .501 & & & \\
\hline It11 & & .787 & & & \\
\hline It12 & & .555 & & & \\
\hline It13 & & .917 & & & \\
\hline It14 & & .533 & & & \\
\hline It15 & & & .511 & & \\
\hline It16 & & & .762 & & \\
\hline It17 & & & .913 & & \\
\hline It18 & & & .899 & & \\
\hline It19 & & & .823 & & \\
\hline It 20 & & & .875 & & \\
\hline It21 & & & .510 & & \\
\hline It22 & & & .634 & & \\
\hline It23 & & & .411 & & \\
\hline It24 & & & .588 & & \\
\hline It 25 & & & .410 & & \\
\hline It26 & & & & .456 & \\
\hline It 27 & & & & .563 & \\
\hline It 28 & & & & .655 & \\
\hline It29 & & & & & .716 \\
\hline It30 & & & & & .412 \\
\hline It31 & & & & & .401 \\
\hline $\begin{array}{l}\% \text { varianza } \\
=81.305\end{array}$ & 24.133 & 25.101 & 23.211 & 4.859 & 4.001 \\
\hline
\end{tabular}

Table 9.Factor analysis

The exploratory analysis results show that all the items meet the retention requirements (Lloret-Segura et al., 2014). The final survey is presented as Appendix I and is structured into five factors and 31 items that measure the perception of stress by school administrators according to three levels: low, medium and high.

Factor I, "Faculty relations", consisting of 8 items (1 to 8, both inclusive), accounts for $19.897 \%$ of the variance, with especially high factor loadings for the items "Reprimanding faculty members for arriving late to work" (.880) and "Reprimanding faculty members for poor classroom control" (.910). The internal consistency of this factor can be considered good, $\alpha=.812$, as it is observed that if any of the items is eliminated, the alpha factor drops.

Factor II, "Family relations", consisting of 6 items (9 to 14, both inclusive), accounts for $24.519 \%$ of the variance, with especially high factor loadings for the items:"Imposing and reporting student 
expulsions" (.787) and "Dealing with cases of school bullying" (.917). The internal consistency of this factor can be considered very good, $\alpha=.910$.

Factor III, "Student relations", consisting of 11 items (15 to 25, both inclusive), accounts for 25.341\% of the variance, with especially high factor loadings for the items: "Dealing with cases of harassment/bullying" (.913), "Dealing with matters related to fights resulting in injuries" (.899) and "Dealing with drug-related matters" (.875). The internal consistency of this factor can be considered very good, $\alpha=.921$.

Factor IV, "Relations with the School Inspection Department", consisting of 3 items (26 to 28, both inclusive), accounts for $11.539 \%$ of the variance, with moderate factor loadings. The internal consistency of this factor can be considered good, $\alpha=.781$.

Factor V, "Relations with external agents", consisting of 3 items (26 to 28, both inclusive), accounts for $8.895 \%$ of the variance, with moderate factor loadings. The internal consistency of this factor can be considered good, $\alpha=.762$.

We then carried out a confirmatory analysis with the following results, using the ML method for parameter estimation: $\chi^{2}=612.212$ based on 248 d.f., $p=.000$; Bentler-Bonett Non-Normed Fit Index $(\mathrm{BNNFI})=.893$; Comparative Fit Index $(\mathrm{CFI})=.902$; Root Mean-Square Error of Approximation $\left(\right.$ RMSEA $=.061$; and $\chi^{2} /$ d.f. $=2.50$. Using the Robust ML method, the following indexes were obtained: $\chi^{2}$ (Satorra-Bentler scaled chi-square) $=501.122$ based on 250 d.f., $p=.000$; Bentler-Bonett Non-Normed Fit Index $(B N N F I)=.902$; Comparative Fit Index $(\mathrm{CFI})=.911$, the comparative fit index guarantees that the model is well-specified, as a value of $\mathrm{CFI} \geq .95$ is currently recognized as indicating a good fit (Hu \& Bentler, 1999); Root Mean-Square Error of Approximation (RMSEA) $=.051$, this result is below the strict limit of .07 set by Steiger $(2007)$; and $\chi^{2 / \text { d.f. }=2.02}$. The indexes show a good fit of the model (Figure 1). 


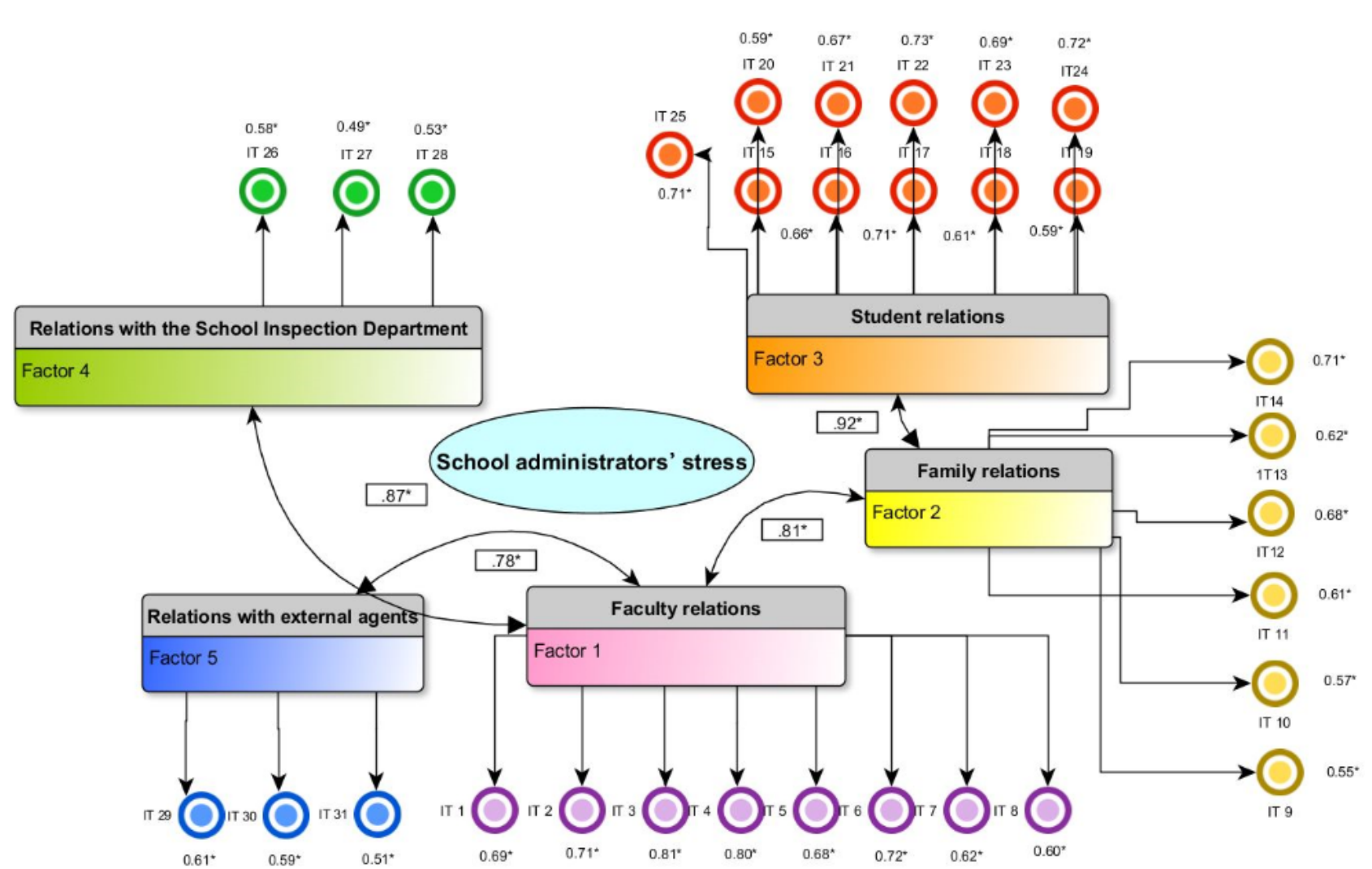

Figure 1. Model of the incidence of personal interactions on the stress of school administrators

\section{Discussion and conclusions}

The incidence of personal relations on the degree of stress suffered by school administrators is an aspect that has not been frequently studied in the scientific literature. The design and validation of a survey that would make it possible to assess the incidence of personal relations on the stress of school administrators would require the participation of experts who are engaged in or have been engaged in administrative work in schools and who have ample teaching and administrative experience. For this reason, this study was approached from a double perspective that is more qualitative than quantitative, drawing on what is known as the "expert competence coefficient", which has enabled us to discriminate more adequately in the selection of experts, as we do not solely rely on a biogram performed on the judges based on questions, but rather more specific self-evaluations that the judge makes about his or her competence to carry out the action that will be requested (Cabero \& Barroso, 2013).

The final survey is presented as Appendix I and is structured into five factors and 31 items that measure the perception of stress by school administrators according to three levels: low, medium and high, with a total score of 155 points possible, according to three intervals: low stress (1-50), moderate 
stress (51-100) and high stress (101-155). The factors with the most incidence on stress have been faculty relations (19.897\% of the total variance). Two actions have been demonstrated to cause high levels of stress among administrators: reprimanding faculty members for arriving late to work and for poor classroom control. These actions have been identified in the literature on school stress as being significant among administrators and faculty (John \& Taylor, 1999; Nosheena, 2010). Dealing with these actions requires specific training in specific areas of human resource management (Caldwell, Calnin \& Cahill, 2002) and organizational practices that report and evaluate these situations before the occur (Mulford, Kendall, Kendall, Lamb \& Hogan, 2001; Huber \& West, 2002).

Relations with families also generate high degrees of work-related stress among administrators (24.519\% of the total variance), highlighting primarily "imposing and informing families about expulsions related to their children and dealing with situations of school bullying". The incidence of dealing with families on the stress of school administrators has also been revealed in different international studies (Hartman \& Chesley, 1998; Giannetti \& Sagarese, 1998; Caspe, 2003). These studies also provide recommendations to administrators about how to minimize stress levels and problems when undertaking this type of actions with families. The recommended strategies are primarily aimed at providing a smooth flow of information to families, as well as guidelines for acting to minimize behavior problems in their children. To tackle these situations, it would be necessary to be able to receive training in interpersonal and communicational competences, a need that has already been identified in different studies (Potter \& Bulach, 2001; Evans, 2004).

The third factor with an influence on the stress of school administrators is student relations $(25.341 \%$ of the total variance). Especially stressful actions are dealing with cases of harassment/bullying and matters related to fights and drugs. These actions have been identified in the scientific literature as highly stressful, especially in the case of school bullying (Merrell, Gueldner, Ross \& Isava, 2008; James, Lawlor, Courtney, Flynn, Henry \& Murphy, 2008). Stress should be placed on a school organization that proposes measures aimed at dealing with stress in these situations in schools. To this end, it would be interesting to develop a better prevention strategy that is not just disciplinary and punitive, but rather corrective (Doménech \& Guerrero, 2005; Teixidó \& Capell, 2006). Likewise, student participation should be promoted through dialog in debates and other activities, as well as the drafting of anti-bullying rules (Bauer et al., 2007; Rytivaara, 2012).

Finally, relations with the School Inspection Department and external community agents represent a moderate influence on the stress of school administrators, with rates of less than $15 \%$ of the total explained variance. In fact, no stress on the part of school administrators has been reported in the Spanish or international literature in relation to these two variables. 


\subsection{Implications and future lines of research}

Teacher and administrator burnout syndrome has increased dramatically in recent years. The administrative function exacerbates even further situations that are perceived as highly stressful. Personal relations in education have changed substantially in recent years, and communication and negotiation with agents in the educational community is a constant and recurring situation faced by administrative teams. Knowing how to handle these situations from an organizational perspective, and also from a personal one, helps improve the management of the educational institution and also to minimize the feeling of stress perceived by administrators. To accomplish this, it is important that the initial and continuing training of school administrators addresses the acquisition of personal conflict management skills in the areas of communication and information management.

\subsection{Limitations of the research}

Research on stress in school administrators has certain characteristics that are noticeably influenced by the context and the educational system. Therefore, the proposed scale is valid for the Spanish context, since it has been adapted to the functions set out in Spanish law and has been designed by professionals who perform or have performed administrative functions in the Spanish socio-educational context. To be applied in other contexts, the corresponding socio-educational adaptation would be necessary.

\section{References}

Álvarez, M. (1993). El perfil del director en el sistema educativo español. Madrid: Universidad Nacional de Educación a Distancia. Tesis doctoral.

Armas, M. (1996). Evaluación de necesidades formativas de los directores escolares de Galicia en el contexto de la reforma educativa. Santiago de Compostela: Universidad de Santiago. Tesis doctoral.

Aydin, A., Sarier, Y., \& Uysal, S. (2013). The Effect of School Principals' Leadership Styles on Teachers' Organizational Commitment and Job Satisfaction. Educational Sciences: Theory and Practice, 13(2), 806-811.

Bell, L., Bolam, R., \& Cubillo, L. (2003) A systematic review of the impact of school leadership and management on student outcomes. Research Evidence in Education Library. London: University of London.

Bentler, P.M. (1990). Comparative fix indexes in structural models. Psychological Bulletin, 107, 238-246. https://doi.org/10.1037/0033-2909.107.2.238 
Bentler, P.M. (2006). EQS Structural Equations Program Manual. Encino, CA: Multivariate Software, Inc.

Browne, M.W., \& Cudeck, R. (1993). Alternative ways of assessing model fit. En K. A. Bollen \& J. S. Long (Eds.), Testing Structural Equation Models (pp. 132-162). Beverly Hills, CA: Sage.

Cabero, J. (2014). Formación del profesorado universitario en TIC. Aplicación del método Delphi para la selección de los contenidos formativos. Educación XX1, 17(1), 109-132.

Cabero, J., \& Barroso, J. (2013). La utilización del juicio de experto para la evaluación de TIC: El coeficiente de competencia experta. Bordón, 65(2), 25-38. https://doi.org/10.13042/brp.2013.65202

Caldwell, B., Calnin, G., \& Cahill, W. (2002). Mission impossible? An international analysis of headteacher/principal training. En N. Bennett, M. Crawford \& M. Cartwright. (eds). Effective educational leadership. London: Paul Chapman \& Open University.

Caspe, M.S. (2003). How teachers come to understand families. eSchool Community Journal, 13(1), $115-131$.

Combs, J.P., Edmonson, S.L., \& Jackson, S.H. (2009). Burnout among elementary school principals. AAS A Journal of Scholarship and Practice, 5(4), 10-15.

Cooper, Cl., \& Kelly, M. (1993). Occupational stress in head teachers: a national UK study. British Journal of Educational Psychology, 63(1), 130-143. https://doi.org/10.1111/j.2044-8279.1993.tb01046.x

Cushing, K.S., Kerrins, J.A., \& Johnstone, T. (2003). Disappearing principals. Leadership, 32(5), 28-37.

De Leon, A.G. (2006). The school leadership crisis: Have school principals been left behind? Carnegie Reporter, 4(1), 1-5.

Evans, R. (2004). Talking with parents today. Independent School, 63(3), 96-100.

Friedman, I.A. (1995). Student behaviour patterns contributing to teacher burnout. The Journal of Educational Research, 88, 281-289. https://doi.org/10.1080/00220671.1995.9941312

Friedman, I.A. (2002). Burnout in school principals: Role related antecedents. Social Psychology of Education, 5(3), 229-251. https://doi.org/10.1023/A:1016321210858

García, L., \& Fernández, S. (2008). Procedimiento de aplicación del trabajo creativo en grupo de expertos. Energética, XXIX(2), 46-50.

Giannetti, C.C., \& Sagarese, M.M. (1998). Turning parents from critics into allies. Educational Leadership, 55(8), 40-42. 
Gmelch, W.H., \& Swent, B. (1981). Stress and the principalship: Strategies for selfimprovement and growth. NASSP Bulletin, 65(449), 16-19. https://doi.org/10.1177/019263658106544903

Grubb, W.N., \& Flessa, J.J. (2006). A job too big for one: Multiple principals and other nontraditional approaches to school leadership. Educational Administration Quarterly, 42, 518-550. https://doi.org/10.1177/0013161X06290641

Halim, L., Samsudin, M.A., Meerah, T.S.M., \& Osman, K. (2006). Measuring science teachers' stress level triggered by multiple stressful conditions. International Journal of Science and Mathematical Education, 4, 727-739. https://doi.org/10.1007/s10763-005-9020-9

Hallinger, P., Bickman, L., \& Davis, K. (1996). School context, principal leadership, and student reading achievement. Elementary School Journal, 96(5), 527-549. https://doi.org/10.1086/461843

Harris, A., \& Adams, T. (2007). Leavers, movers and stayers: The role of workplace conditions in mobility decisions. The Journal of educational research article, 3(4), 20-30.

Hartman, D.M., \& Chesley, G. (1998). Destressing distressed parents. Education Digest, 63(5), 25-27.

Hildebrandt, S., Kristensen, K., Kanji, G., \& Dahlgaard, J.J. (1991). Quality culture and TQM. Total Quality Management, 2(1), 1-15. https://doi.org/10.1080/09544129100000001

Hoyle, R.H. (1995). The structural equation modeling approach: Basic concepts and fundamental issues. In R.H. Hoyle (Ed.), Structural equation modeling, concepts, issues, and applications (pp. 1-15). Thousand Oaks, CA: Sage

Hu, L., \& Bentler, P.M. (1999). Cutoff criteria for fit indexes in covariance structure analysis: Conventional criteria versus new alternatives. Structural Equation Modeling, 6(1), 1-55. https://doi.org/10.1080/10705519909540118

Huber, S. \& West, M. (2002). Developing school leaders: A critical review of current practices, approaches and issues, and some directions for the future. In K. Leithwood, P. Hallinger, G. Furman, P. Gronn, J. MacBeath, B. Mulford, \& K. Riley. (eds.), Second international handbook of educational leadership and administration (pp. 1071-1101). Norwell, MA: Kluwer. https://doi.org/10.1007/978-94-010-0375-9_37

James, D.J., Lawlor, M., Courtney, P., Flynn, A., Henry, B., \& Murphy, N. (2008). Bullying behaviour in secondary schools: What roles do teachers play?. Child Abuse Rev., 17, 160-173. https://doi.org/10.1002/car.1025 
John, M.C. \& Taylor, J.W. (1999, April). Leadership style, school climate, and the institutional commitment of teachers. International Forum, 2(1), 25-57.

Landeta, J. (2002). El método Delphi: Una técnica de previsión del futuro. Barcelona: Ariel.

Lloret-Segura, S., Ferreres-Traver, A., Hernández-Baeza, A., \& Tomás-Marco, I. (2014). El análisis factorial exploratorio de los ítems: Una guía práctica, revisada y actualizada. Anales de Psicología, 30(3), 1151-1169. https://doi.org/10.6018/analesps.30.3.199361

LOMCE (2013). Ley Orgánica 8/2013, de 9 de diciembre, para la mejora de la calidad educativa. BOE núm. 295, de 10 de diciembre de 2013.

López, A. (2008). La moderación de la habilidad diagnóstico patológico desde el enfoque histórico cultural para la asignatura Patología Veterinaria. Revista Pedagógica Universitaria, 13(5), 51-71.

Maslach, C. (1982). Understanding burnout: Definitional issues in analyzing a complex phenomenon. En WS. Paine (Ed), Job stress and burnout (pp. 29-40). Beverly Hills CA: Sage.

Maslach, C. (2003). Burnout: The cost of caring. Englewood Cliffs, NJ: Prentice-Hall.

Maslach, C., Schaufeli, W.B., \& Leiter, M.P. (2001). Job burnout. Annual Review of Psychology, 52, 397-422. https://doi.org/10.1146/annurev.psych.52.1.397

Mengual, S. (2011). La importancia percibida por el profesorado y el alumnado sobre la inclusión de la competencia digital en Educación Superior. Alicante: Departamento de Didáctica General y Didácticas específicas de la Facultad de Alicante.

Merrell, K.W., Gueldner, B.A., Ross, S.W., \& Isava, D.M. (2008). How Effective Are School Bullying Intervention Programs? A Meta-Analysis of Intervention Research. School Psychology Quarterly, 23(1), 26-42. https://doi.org/10.1037/1045-3830.23.1.26

Mulford, B., Kendall, L., Kendall, D., Lamb, S., \& Hogan, D. (2001). Decision making in secondary schools. International Studies in Educational Administration, 29(3), 49-73.

Murray, J., \& Hammons, J. (1995). Delphi. A versatile methodology for conducting qualitative research. The Review of Higher Education, 18(4), 423-436. https://doi.org/10.1353/rhe.1995.0008

Nosheena, T. (2010). The relationship between principal leadership style and teacher occupational stress. Journal of Research and Reflections in Education, 5(2), 107-115.

OECD (2014). TALIS 2013 Results: An International Perspective on Teaching and Learning. Paris: OECD Publishing. https://doi.org/10.1787/9789264196261-en 
Patton, M.Q. (1987). Depth Interviewing. En M.Q. Patton, How to Use Qualita tive Methods in evaluation (pp. 108- 143). London: Sage Publications.

Pawlas, G.E. (1996). Year-round education: Florida principal's perspectives. ERS Spectrum, 14(3), 42-74.

Pines, A., \& Aronson, E. (1988). Carrer burnout: causes and cures. New York: The Free Press.

Potter, L., \& Bulach, C. (2001). Do's and don't of parent-teacher conferences. Education Digest, 66(9), $37-40$.

Powell, C. (2003). The Delphi technique: Myths and realities. Journal of Advanced Nursing, 41(4), 376-382. https://doi.org/10.1046/j.1365-2648.2003.02537.x

Queen, J.A., \& Queen, P.S. (2005). The frazzled principal's wellness plan: Reclaiming time, managing stress, and creating a bealthy lifestyle. Thousand Oaks, CA: Sage Publications, Inc.

Real Decreto (1996). Real Decreto 83/1996, de 26 de enero, por el que se aprueba el Reglamento Orgánico de los Institutos de Educación Secundaria. BOE núm. 45, de 21 de febrero de 1996.

Rowe, G., \& Wright, G. (1999). The Delphi technique as a forecasting tool. Issues and analysis. International Journal of Forecasting, 15(4), 353-375. https://doi.org/10.1016/S0169-2070(99)00018-7

Sarros, J.C. (1988). School administrators write about burnout: Individual and organizational implications. British Educational Research Journal, 14(2), 175-190. https://doi.org/10.1080/0141192880140207

Steiger, J.H. (2007). Understanding the limitations of global fit assessment in structural equation modeling. Personality and Individual Differences, 42(5), 893-98. https://doi.org/10.1016/j.paid.2006.09.017

Tejero-González, C.M. ${ }^{a}$, \& Fernández-Díaz, M.J. (2010). Estrés laboral y dirección escolar. Escala de medición y jerarquía de estresores. Bordón, 62(1), 123-137.

Troman, G. (2000). Teacher stress in the low-trust society. British Journal of Sociology of Education, 21, 331-353. https://doi.org/10.1080/713655357

Vázquez-Cano, E. (2016). Dificultades del profesorado para planificar, coordinar y evaluar competencias clave. Un análisis desde la Inspección de Educación. Revista Complutense de Educación, 27(3), 1061-1083.

Vázquez-Cano, E. (2017). La inspección y supervisión de los centros educativos. Madrid: UNED.

Vázquez-Cano, E., Sevillano, M.'L., \& Méndez, M.A. (2011). Programar en Primaria y Secundaria. Madrid: Pearson. https://doi.org/10.5209/rev_RCED.2016.v27.n3.47400 
Whan, L.D., \& Thomas, A.R. (1996). The principalship and stress in the workplace: An observational and physiological study. Journal of School Leadership, 6(4), 444-465.

Whitaker, K.S. (1995). Principal burnout: Implications for professional development. Journal of Personnel Evaluation in Education, 9, 287-296. https://doi.org/10.1007/BF00972643

Williams, P.L., \& Webb, C. (1994). The Delphi technique: A methodological discussion. Journal of Advanced Nursing, 19, 180-186. https://doi.org/10.1111/j.1365-2648.1994.tb01066.x

Witkin, B.R., \& Altschuld, J.W. (1995). Planning and conducting needs assessment: A practical guide. Thousand Oaks, Sage. 


\section{Annex I}

\begin{tabular}{|c|c|c|c|c|c|}
\hline \multicolumn{6}{|c|}{ 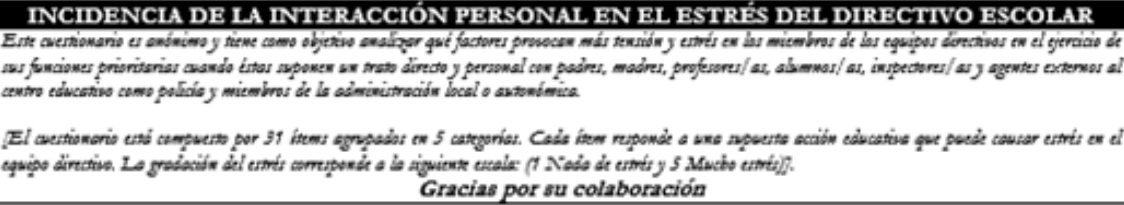 } \\
\hline \multicolumn{6}{|c|}{ Datos generales } \\
\hline \multicolumn{6}{|l|}{ Sexo: } \\
\hline \multicolumn{6}{|l|}{ Edad: } \\
\hline \multicolumn{6}{|l|}{ Estado civil/personal: casado, soltero, dirorciado, con hijos } \\
\hline \multicolumn{6}{|l|}{ Años de experienciz en equipos directiros: } \\
\hline \multicolumn{6}{|l|}{ 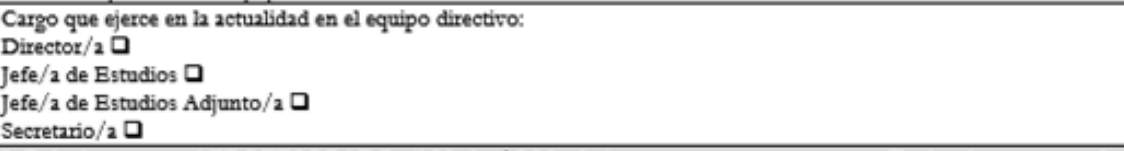 } \\
\hline \multirow{2}{*}{$\begin{array}{l}\text { I. Relaciones con el PROFESORADO. (1 Nada / } 5 \text { Mucho) } \\
\text { 1. Apercibir al profesorado por retrasos en su jomada laboral }\end{array}$} & \multicolumn{5}{|c|}{ Tachar lo que proceda } \\
\hline & \begin{tabular}{l|l|l|} 
& 1 \\
\end{tabular} & 2 & 3 & 4 & 5 \\
\hline 2. Apercibir al profesorado por ausencias injustificadas & 1 & 2 & 3 & 4 & 5 \\
\hline 3. Apercibir al profesondo por un deficiente control del $2 \mathrm{nla}$ & 1 & 2 & 3 & 4 & 5 \\
\hline 4. Apercibir al profesondo por no atender adecuadamente las guardias (aula o recreo) & 1 & 2 & 3 & 4 & 5 \\
\hline 5. Comunicar al profesorado quejas sobre metodología en su materia & 1 & 2 & 3 & 4 & 5 \\
\hline 6. Desarrollo de los Claustros & 1 & 2 & 3 & 4 & 5 \\
\hline 7. Desarrollo de las CCP & 1 & 2 & 3 & 4 & 5 \\
\hline 8. Desarrollo de los Consejos Escolares & \begin{tabular}{l|l} 
& 1 \\
\end{tabular} & 2 & 3 & 4 & 5 \\
\hline \multicolumn{6}{|c|}{ II. Relaciones con las FAMIILIAS. (1 Nada / 5 Mucho) } \\
\hline 9. Informar sobre problemas disciplinarios del alumnado & \begin{tabular}{l|l|l|l} 
& 1 \\
\end{tabular} & 2 & 3 & 4 & 5 \\
\hline 10. Informar sobre ausencias injustificadas del alumnado & 1 & 2 & 3 & 4 & 5 \\
\hline 11. Imponer e informax sobre expulsiones del alumnado & 1 & 2 & 3 & 4 & 5 \\
\hline 12. Atender reclamaciones de notas & 1 & 2 & 3 & 4 & 5 \\
\hline 13. Atender reclamaciones sobre cambios en la clase/grupo en el que se encuentra hijo/2 & 1 & 2 & 3 & 4 & 5 \\
\hline 14. Desarrollo de reuniones grupales con los padres y madres al inicio de curso & \begin{tabular}{l|l} 
& 1 \\
\end{tabular} & 2 & 3 & 4 & 5 \\
\hline \multicolumn{6}{|c|}{$\begin{array}{l}\text { III. Relaciones con el ALUMNADO. (1 Nada / } 5 \text { Afucho) } \\
\text { proceda }\end{array}$} \\
\hline 15. Imponer medidas correctoras que no implican expulsión del centro & \begin{tabular}{l|l|} 
& 1 \\
\end{tabular} & 2 & 3 & 4 & 5 \\
\hline 16. Imponer medidas correctoras que implican expulsión del centro & 1 & 2 & 3 & 4 & 5 \\
\hline 17. Atender casos de acoso/bulltina & 1 & 2 & 3 & 4 & 5 \\
\hline 18. Atender sucesos relacionados con peleas con daño físico & 1 & 2 & 3 & 4 & 5 \\
\hline 19. Atender sucesos relacionados con robos & 1 & 2 & 3 & 4 & 5 \\
\hline 20. Atender sucesos relacionados con drogas & 1 & 2 & 3 & 4 & 5 \\
\hline 21. Atender sucesos relacionados con desperfectos en el centro & 1 & 2 & 3 & 4 & 5 \\
\hline 22. Atender casos de alumnado con necesidad de apoyo espećfíco & 1 & 2 & 3 & 4 & 5 \\
\hline 23. Atender casos de uso indebido de teléfonos móriles $\mathrm{y}$ otros dispositivos dipitales & 1 & 2 & 3 & 4 & 5 \\
\hline 24. Atender alumnado inmigrante & 1 & 2 & 3 & 4 & 5 \\
\hline 25. Atender sucesos relacionados con 12 higiene & 1 & 2 & 3 & 4 & 5 \\
\hline \multicolumn{6}{|l|}{$\begin{array}{l}\text { IV. Relaciones con la INSPECCIÓN EDUCATIVA. (1 Nada / } 5 \text { Afucho) } \\
\text { proceda }\end{array}$} \\
\hline 26. Visitas programas del Inspector/a & \begin{tabular}{l|l|l} 
& 1 \\
\end{tabular} & 2 & 3 & 4 & 5 \\
\hline 27. Visitas por sorpresa del Inspector $/ \mathbf{2}$ & 1 & 2 & 3 & 4 & 5 \\
\hline 28. Procesos de erziluzeión directivz & \begin{tabular}{l|l} 
& 1 \\
\end{tabular} & 2 & 3 & 4 & 5 \\
\hline $\begin{array}{l}\text { V. Relaciones con AGENTES EXTERNOS. (1 Nada / } 5 \text { Mucho) } \\
\text { proceda }\end{array}$ & Tacha & rlo & & & \\
\hline 29. Intervención de ha Policía & 1 & 2 & 3 & 4 & 5 \\
\hline 30. Relaciones con el Aruntamiento & 1 & 2 & 3 & 4 & 5 \\
\hline 31. Relaciones con la Administración educativa & 1 & 2 & 3 & 4 & 5 \\
\hline
\end{tabular}

Intangible Capital, 2017 (www.intangiblecapital.org)

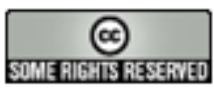

Article's contents are provided on an Attribution-Non Commercial 3.0 Creative commons license. Readers are allowed to copy, distribute and communicate article's contents, provided the author's and Intangible Capital's names are included. It must not be used for commercial purposes. To see the complete license contents, please visit http://creativecommons.org/licenses/by-nc/3.0/. 